\title{
Physicochemical and Sensory Properties of Appenzeller Cheese Supplemented with Shrimp Powder
}

\author{
Jai-Sung Lee, Hee-Young Choi ${ }^{1}$, Kyoung-Hee Kim¹, \\ Soon-Sil Chun ${ }^{2}$, and Inhyu Bae* \\ Department of Animal Science and Technology, Sunchon National University, Suncheoni 540-950, Korea \\ ${ }^{1}$ Imsil Institute of Cheese Science, Imsil 566-700, Korea \\ ${ }^{2}$ Department of Food and Nutrition, Sunchon National University, Suncheon 540-950, Korea
}

\begin{abstract}
The effects of adding shrimp (Periclimenes imperator) powder to Appenzeller cheese on quality and characteristics during ripening were investigated. Cheese samples were prepared containing $1.0 \%, 2.0 \%$, and $3.0 \%$ shrimp powder. Changes in the lactic acid bacterial populations, $\mathrm{pH}$, water-soluble nitrogen concentrations, consumer acceptability, colour and texture were monitored during ripening. The addition of shrimp powder did not affect the appearance or consumer sensory characteristics of the cheeses. Likewise, cheese cohesiveness, fracturability, and springiness were not significantly altered. It was concluded that the quality of the Appenzeller cheese was not affected by adding shrimp powder.
\end{abstract}

Key words: appenzeller cheese, shrimp powder, ripening

Received July 8, 2014 / Revised March 2, 2015 / Accepted March 9, 2015

\section{Introduction}

Appenzeller cheese, a traditional cheese of the Appenzeller region located in northeastern Switzerland, is made from the raw milk of cows that graze on green grass during the summer that is ripened for 4-6 mos. Traditionally, this semi-hard cheese has a disk shape and weighs 5-6.75 $\mathrm{kg}$, with a $45 \%$ fat content and $42-52 \%$ moisture content (Juliet et al., 1999; Kessler et al., 1990; Kosikowski and Mystry, 1997). Appenzeller cheese has attracted attention for domestic production in Korea due to its taste and flavour, which Korean consumers would consider palatable (Heo et al., 2006; Lee, 2006).

Shrimp contain bioactive compounds, including chitin and chitosan (Ryu, 1992). Chitin is a type of muco-polysaccharide present in the shells of crustaceans, such as shrimp and crab. Chitosan is obtained through deacetylation to facilitate the easy absorption of chitin into the body. This compound suppresses ageing by activating aged

\footnotetext{
*Corresponding author: Inhyu Bae, Department of Animal Science and Technology, Sunchon National University, Suncheon 540-950, Korea. Tel: +82-61-750-3233, Fax: +82-61-750-3233, E-mail: ihbae@scnu.ac.kr
}

cells, helps to prevent circulatory disease, strengthens the immune system, and binds harmful cholesterol for excretion from the body (Martin and Flick, 1990). Additionally, chitosan is able to suppress cancer cell proliferation, reduce blood pressure by absorbing chloride ions and discharging them from the body, promote the proliferation of beneficial intestinal bacteria, and improve glycaemic control and liver function (Kim, 2004). Recently, chitosan has been evaluated as a carrier of hydrophobic anticancer drugs (Park et al., 2008). Studies on processed food derived from shrimp, including shrimp powder (Kim et al., 2009), sauce made from by-products of shrimp, crab, and lobster (Lee et al., 2007), sauces made from shrimp and crab (Lee, 2004), teriyaki sauce supplemented with shrimp by-products (Cho et al., 2011), and fish cakes supplemented with shrimp powder (Seo and Cho, 2012), have been conducted. However, no research has been performed on natural cheeses containing shrimp.

The purpose of this study was to combine shrimp powder with natural cheese, a traditional fermented food in the western world, to develop a Korean-type natural cheese with quality equal to that of western-type cheese supplemented with shrimp powder to increase the availability of seafood in Korea. 


\section{Materials and Methods}

\section{Raw milk}

Fresh raw milk (pH 6.6-6.8) was collected from Holstein-Friesian cows raised in a vivarium affiliated with Sunchon National University (Korea) and used to produce Appenzeller cheese.

\section{Starter}

A working starter culture was obtained after 2 transfers, and it was autoclaved $\left(95^{\circ} \mathrm{C}, 30 \mathrm{~min}\right)$ and reconstituted with skim milk ( $10 \%$ of DM). The milk was cooled to 32 ${ }^{\circ} \mathrm{C}$ and then inoculated with the following starter bacteria: ALP-DIP D (CHOOZIT Alp D, 2005, Danisco, Denmark; Lactococcus lactis subsp. cremoris, Lactococcus lactis subsp. lactis, Lactococcus lactis subsp. lactis biovar. diacetylactis, Streptococcus salivarius subsp. thermophilus, Lactobacillus helveticus, and Lactobacillus lactis) and KAZU 1 (Rhodia Co., Paris, France; Lactococcus lactis subsp. lactis, Lactococcus lactis subsp. cremoris, Lactococcus lactis subsp. lactis biovar. diacetylactis, and Lactobacillus helveticus). The starter bacteria (ALP-DIP D: $1.0 \times 10^{9} \mathrm{CFU} / \mathrm{g}$, and KAZU $1: 1.0 \times 10^{9} \mathrm{CFU} / \mathrm{g}$ ) was incubated at $32^{\circ} \mathrm{C}$ and $\mathrm{pH}$ 4.7-4.8 and kept at $4^{\circ} \mathrm{C}$ until use. Each set of starter bacteria was inoculated at $0.75 \%$ the volume of the raw milk.

\section{Shrimp powder}

For this experiment, dry shrimp was purchased from FreshO2 (Korea), crushed with a KFY-500 crusher (Korea Medi Co., Ltd., Korea), passed through a 40 mesh sieve (Chung Gye Sang Gong Sa Co., Ltd., Korea), air-dried at room temperature until the water content was $32.67 \pm 0.13 \%$ (fat: $2.02 \pm 0.12 \%$, protein: $40.66 \pm 0.07 \%$, salt: $1.39 \pm 0.1 \%$, and total solids: $67.32 \pm 0.13 \%$ ) and sterilized at $121^{\circ} \mathrm{C}$ for $15 \mathrm{~min}$. The shrimp powder was then frozen at $-18^{\circ} \mathrm{C}$ until use.

\section{Analysis of chemical components}

The general components of the cheese were analysed according to the method of the AOAC (1990). The moisture content was analysed with the oven-drying method. The crude protein content was determined using the Kjeldahl method with an automatic protein analyser (BÜCHI Labortechnik AG, Switzerland), and crude fat was measured by the Roese-Gottlieb method. To analyse the general components of the shrimp powder, it was used to fill $90 \times 15 \mathrm{~mm}$ Petri dishes and the fat, protein, moisture, salinity, and total solid contents were measured with a
FoodScan $^{\mathrm{TM}}$ dairy analyser (Denmark).

\section{Manufacturing Appenzeller cheese supplemented with shrimp powder}

To manufacture the cheese, we followed the method described by Choi et al. (2011) based on the technique of Kessler et al. (1990), with modifications to accommodate the nature of Korean raw milk. To give the traditionally mild flavour to the Appenzeller cheese, an appropriate amount of clean water was added at approximately $10 \%$ of the volume of the raw milk, pasteurized at $63^{\circ} \mathrm{C}$ for 30 min and cooled to $32^{\circ} \mathrm{C}$. The total protein, fat and solid contents of the pasteurized milk were $3.25 \pm 0.1,4.05 \pm 0.1$, and $12.43 \%$ respectively. The pasteurized milk was poured into a cheese vat set to $32^{\circ} \mathrm{C}$, and each starter was inoculated at $0.75 \%$ of the volume of the raw milk and incubated for $30 \mathrm{~min}$. Then, a calcium chloride solution (20 $\mathrm{mL} / 100 \mathrm{~kg}$; CALCIO, Danisco, Denmark) was added.

Rennet was added to each cheese vat when the temperature of the milk reached $32^{\circ} \mathrm{C}$ and the $\mathrm{pH}$ decreased by approximately 0.30 unit due to lactic acid formation caused by the starter. A double-strength rennet $(19 \mathrm{~mL} / 100$ kg; 290 Halal Calf Rennet, Christian Hansen, Denmark) was diluted 20 -fold with distilled water. Once a proper coagulum was formed (after approximately $30 \mathrm{~min}$ ), the curd was cut into cubes of $5.0-7.0 \mathrm{~mm}^{3}$ in size. The cut curd was allowed to settle for $4 \mathrm{~min}$ to heal and then stirred at $32^{\circ} \mathrm{C}$ for $60 \mathrm{~min}$. Next, $70^{\circ} \mathrm{C}$ water at $10 \%$ of the volume of the milk was added to raise the vat temperature from $32^{\circ} \mathrm{C}$ to $39^{\circ} \mathrm{C}$ at a rate of $1.0^{\circ} \mathrm{C}$ every $5 \mathrm{~min}$. The solution was then stirred for more than $40 \mathrm{~min}$ before the whey was removed. After the removal of the whey, shrimp powder $(1.0 \%, 2.0 \%$, or $3.0 \%)$ was added to the curds. The curds were formed, pressed, and salted in $20 \%$ (wt/ wt) brine for $8 \mathrm{~h} / \mathrm{kg}$. Next, the cheese was dried for surface formation for $1 \mathrm{wk}$ in the refrigerator at $7^{\circ} \mathrm{C}$ and ripened for $16 \mathrm{wk}$ at $14^{\circ} \mathrm{C}$ and $90-95 \%$ relative humidity $(\mathrm{R} /$ $\mathrm{H})$.

\section{Measuring changes in the viable cell count of the cheese}

Changes in the viable cell counts of lactic acid bacteria (LAB) during cheese ripening were evaluated by collecting cheese samples every $3 \mathrm{wk}$ and mixing them with sterile saline solution at a ratio of 2:1 $(40 \mathrm{~mL}$ saline: $20 \mathrm{~g}$ cheese). The samples were then homogenized three times for $2 \mathrm{~min}$ at 20,000 rpm with a homogenizer (M. Zipper $\mathrm{GmbH}$, Germany). The viable cell counts were determined by standard plate count agar methods (Marshal, 1993). 
Serially diluted aliquots of the samples were subsequently plated on BCP agar (Eiken Chemical Co., Ltd., Japan) and incubated for $48 \mathrm{~h}$ at $37^{\circ} \mathrm{C}$. Plates containing 30-300 colonies were counted, and the results are presented as the $\log$ of the viable counts in CFU/g.

\section{Measurement of cheese $\mathrm{pH}$}

The $\mathrm{pH}$ changes during the cheese ripening process were measured every $3 \mathrm{wk}$ for $15 \mathrm{wk}$ using a $\mathrm{pH}$ metre (Istek Co. Model 720p, Korea). The cheese sample was mixed with saline at a 2:1 ratio $(\mathrm{v} / \mathrm{w})$ and then homogenized for $2 \mathrm{~min}$ at 20,000 rpm with a homogenizer (M. Zipperer $\mathrm{GmbH}$, Germany) before the $\mathrm{pH}$ was measured.

\section{Changes in water-soluble nitrogen (WSN) concen- tration during ripening}

To measure the level of total protein degradation during cheese ripening, changes in the WSN concentration were measured as previously described by Bütikofer et al. (1993).

First, sterile saline and cheese were blended at a ratio of 2:1 (v/w) with a homogenizer (M. Zipper GmbH, Germany). Next, $2.5 \mathrm{~mL}$ of sample was collected after removing upper-level fat by centrifugation (Supra 25K; Hannil Science Industrial, Korea) at $3,000 \mathrm{~g}$ for $30 \mathrm{~min}$ at $5^{\circ} \mathrm{C}$. The liquid remaining after the removal of the upper-level fat was filtered with Whatman No. 2 paper (GE Healthcare Korea, Korea). Subsequently, $2.5 \mathrm{~mL}$ of filtrate was mixed with $5.0 \mathrm{~mL}$ of $12 \%$ trichloroacetic acid (TCA, ACROS, USA) (Reagent A) and $0.5 \mathrm{~mL}$ of distilled water as previously described by Hull (1947), left at room temperature for $20 \mathrm{~min}$, and filtered. Colour was developed by mixing $2.5 \mathrm{~mL}$ of the filtrate with $5.0 \mathrm{~mL}$ of Reagent B (75 g sodium carbonate; Wako, Pure chemical Ind. Ltd., Japan), $10 \mathrm{~g}$ sodium hexametaphosphate (in $500 \mathrm{~mL}$ distilled water; Yakuri Pure chemical Co. Ltd., Japan) and $1.5 \mathrm{~mL}$ of Reagent C (50 mL phenol (in $100 \mathrm{~mL}$ distilled water; Junsei Chemical Co. Ltd., Japan) and incubating the solution for $30 \mathrm{~min}$ at $30^{\circ} \mathrm{C}$ in a water bath. After colour development, the WSN concentration was measured at an absorbance of $570 \mathrm{~nm}$ with a UV spectrophotometer (Mecasys Co. Ltd., Optizen 1412 V., Korea) and calculated based on a regression line equation obtained using tyrosine as a standard $\left(\mathrm{y}=0.787 \mathrm{x}, \mathrm{R}^{2}=0.999\right)$.

\section{Measurement of cheese colour}

To measure the colour, lightness (L), greenness (a), and yellowness (b) of the cheese, samples that had ripened for 16 wk were analysed with a Colour Meter ZE 2000 (Nippon Denshoku Co. Ltd., Japan).

\section{Assessment of cheese texture}

To measure the texture, hardness, fracturability, adhesiveness, cohesiveness, springiness, gumminess, chewiness, and resilience of the cheese, a force-time curve was generated by collecting cheese samples that had ripened for $16 \mathrm{wk}$ and analysing them with a $100 \mathrm{~mm}$ compression plate in a texture analyser (Model TA-XT2i, Stable Micro Systems, England). Each sample was analysed in duplicate.

\section{Consumer acceptability test}

To evaluate the consumer acceptability of the cheese, a sensory test was carried out with a questionnaire, using a 9-point scale. A total of 100 students from the Department of Food Science and Nutrition at Sunchon National University participated. The cheese used for this test had been ripened for $16 \mathrm{wk}$. The consumers evaluated the cheese samples for characteristics such as colour, flavour, softness, buttery flavour, saltiness, and shrimp flavour using an intensity scale, ranging from 1 point (very weak) to 9 points (very strong). In addition, the consumers evaluated the overall acceptability of the cheese using a hedonic scale, ranging from 1 (dislike extremely) to 9 (like extremely) points. The samples $(15 \mathrm{~g})$ were given to the students on a white plastic plate. The ages and genders of the participating students were recorded.

\section{Statistical analysis}

All statistical analyses were performed using SAS version 9.0 (SAS Institute Inc., USA). The means were verified with Fisher's least significant difference test. P-values $<0.05$ were considered to be significant.

\section{Results and Discussion}

\section{Chemical component analysis}

The results of chemical component analysis of the cheese supplemented with shrimp powder are shown in Tables 1 and 2. The moisture content was somewhat lower for the supplemented cheese $(41.81-43.26 \%)$ than the control sample $(44.53 \%)$. This finding may have been caused by moisture loss due to the addition of the shrimp powder because the moisture content of the crushed shrimp powder was lower $(32.67 \%)$ than that of the control cheese. Additionally, the crude protein content appeared to be slightly higher for the shrimp powder-supplemented cheese than the control cheese because that of the shrimp powder itself is high (40.66\%), as previously reported (Kim et al., 2009). 
Table 1. Chemical composition of the Appenzeller cheese supplemented with shrimp powder

\begin{tabular}{ccccc}
\hline \hline Sample & \multicolumn{4}{c}{ Shrimp Powder (\%) } \\
\cline { 2 - 5 } & Control & $1.0 \%$ & $2.0 \%$ & $3.0 \%$ \\
\hline Moisture & $44.53 \pm 0.177^{\mathrm{a}}$ & $43.26 \pm 0.087^{\mathrm{b}}$ & $42.84 \pm 0.087^{\mathrm{b}}$ & $41.81 \pm 0.091^{\mathrm{c}}$ \\
Crude ash & $3.55 \pm 0.015^{\mathrm{b}}$ & $4.01 \pm 0.026^{\mathrm{a}}$ & $4.46 \pm 0.043^{\mathrm{a}}$ & $4.43 \pm 0.020^{\mathrm{a}}$ \\
Crude fat & $29.16 \pm 0.147^{\mathrm{b}}$ & $29.37 \pm 0.130^{\mathrm{a}}$ & $29.63 \pm 0.086^{\mathrm{a}}$ & $29.26 \pm 0.135^{\mathrm{a}}$ \\
Crude protein & $22.76 \pm 0.255^{\mathrm{c}}$ & $23.36 \pm 0.237^{\mathrm{b}}$ & $23.07 \pm 0.079^{\mathrm{b}}$ & $24.05 \pm 0.252^{\mathrm{a}}$ \\
\hline
\end{tabular}

The data are presented as the mean S.D. $(n=15)$. The mean values with different superscript letters in each row are significantly different $(p<0.05)$.

Table 2. Chemical composition of the shrimp powder (\%)

\begin{tabular}{ccccc}
\hline \hline Fat & Moisture & Protein & Salt & Total solids \\
\hline $2.02 \pm 0.12$ & $32.67 \pm 0.13$ & $40.66 \pm 0.07$ & $1.39 \pm 0.1$ & $67.32 \pm 0.133$ \\
\hline
\end{tabular}

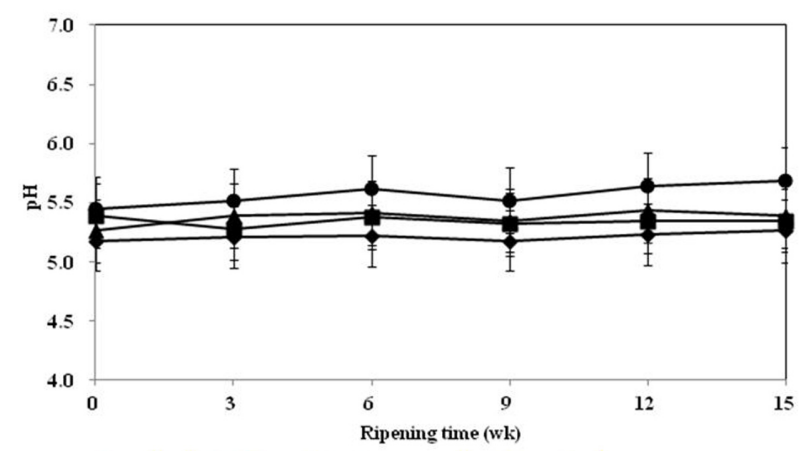

Fig. 1. Changes in the pH of the Appenzeller cheese supplemented with shrimp powder during ripening. $\diamond-\bullet$ control cheese, $\square-$ - cheese containing $1.0 \%$ shrimp powder, $\triangle$ - $\triangle$ cheese containing $\mathbf{2 . 0 \%}$ shrimp powder, and - - cheese containing $3.0 \%$ shrimp powder.

\section{Changes in $\mathbf{p H}$}

The $\mathrm{pH}$ value changes observed during the ripening procedure are shown in Fig. 1. After 12 wk of ripening, the $\mathrm{pH}$ values of the cheese supplemented with the shrimp powder ranged from 5.3-5.6, which did not significantly differ from those of the control cheese; however, the supplemented cheese tended to have a slightly higher $\mathrm{pH}$ (by approximately $3.0 \%$ ). This finding was thought to have been attributed to alkaline components derived from the shrimp powder. Our findings are similar to those of several previous reports (McSweeney and Fox, 1997; Puchades et al., 1989; Visser, 1977a, 1977b) indicating that changes in $\mathrm{pH}$ may be caused by free amino acids produced by cheese protein degradation as well as weakly or completely undissociated acids, such as acetic acid or carbonic acid, and the decomposition of non-volatile components and lactic acid during cheese ripening. Lawrence et al. (1987) have also reported a slight gradual increase in $\mathrm{pH}$ during the cheese ripening process.

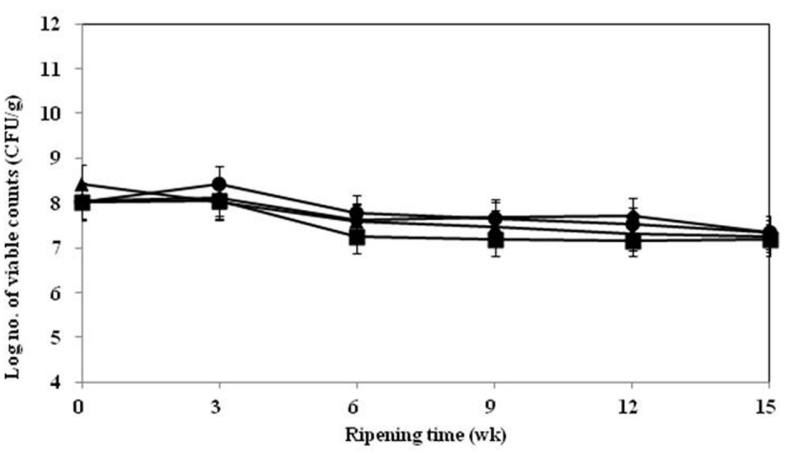

Fig. 2. Changes in the lactic acid bacteria counts in the Appenzeller cheese supplemented with shrimp powder during ripening. $\bullet-\diamond$ control cheese, $\square-\square$ cheese containing $1.0 \%$ shrimp powder, $\Delta-\Delta$ cheese containing $2.0 \%$ shrimp powder, and $\bullet-\bullet$ cheese containing $\mathbf{3 . 0} \%$ shrimp powder.

\section{Change in viable cell count}

The viable cell counts of LAB in the Appenzeller cheese supplemented with shrimp powder were not significantly different from those of the control group during the ripening period, as shown in Fig. 2. The viable cell counts tended to decrease equally in both types of cheeses during the ripening period.

\section{Changes in the WSN concentration}

Changes in WSN concentration during the ripening period have been used to determine the degree of cheese ripening (Ardõ, 1999; Dahlberg and Kosikowski, 1947; Kuchroo and Fox, 1982). In the present study, the WSN concentration tended to increase over time, which was probably due to proteolysis (Fig. 3). This increase in the WSN concentration is believed to be the result of an increase in the breakdown of casein during the ripening process. Our findings are in agreement with those reported by Oberg et al. (1986), who have found that WSN levels 


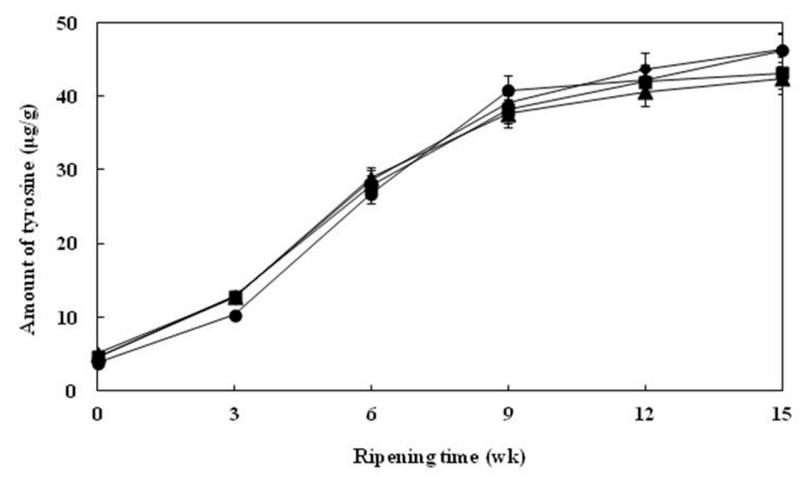

Fig. 3. Changes in the WSN concentration of the Appenzeller cheese supplemented with shrimp powder during ripening. $\bullet-\downarrow$ control cheese, $\square-\square$ cheese containing $1.0 \%$ shrimp powder, $\triangle-\triangle$ cheese containing $2.0 \%$ shrimp powder, and $\bullet-\bullet$ cheese containing $3.0 \%$ shrimp powder.

increase because of the generation of abundant nitrogen compounds in ripening cheese by the action of rennet and proteolytic enzymes in the lactic starter. The tendency for nitrogen compound levels to increase during the ripening of cheese has also been noted by Bergamini et al. (2006) and Tejada et al. (2008).

\section{Colour}

The colour changes of the Appenzeller cheese supplemented with shrimp powder observed during ripening are presented in Table 3. As the cheese ripened, the lightness (L) of the supplemented cheese decreased. The lightness value was the lowest during the $12^{\text {th }} \mathrm{wk}$, and cheese that contained higher levels of shrimp powder had lower $\mathrm{L}$ values $(p<0.05)$. The greenness of the supplemented cheese decreased slightly compared to that of the control group.
This value was lower in the presence of higher concentrations of shrimp powder. These findings are consistent those of Jeon (2006), who has shown that the colour of cheese changes with the increasing addition of chlorella. In contrast with $L$ values and a values, the $b$ values for the control and shrimp-supplemented cheeses were increased during ripening.

\section{Texture analysis}

The changes in the Appenzeller cheese texture due to the addition of shrimp powder are shown in Table 4 . The hardness of the cheese containing 3.0\% shrimp powder was the greatest at wk 0 of ripening. After the $3^{\text {rd }}$ wk of ripening, the control sample as well as the cheeses supplemented with $1.0 \%$ and $3.0 \%$ shrimp powder had the highest hardness values. Until the $9^{\text {th }}$ wk of ripening, high adhesiveness values were observed for the control cheese and the samples with the least amounts of shrimp powder. During the $12^{\text {th }} \mathrm{wk}$, no significant differences in the cheese samples supplemented with shrimp powder were observed. No significant differences in fracturability were observed for the cheese samples supplemented with shrimp powder during the ripening period, except during the $9^{\text {th }}$ $w k$. No significant differences in cohesiveness or springiness were observed among the cheese samples $(p<0.05)$.

\section{Consumer acceptability test results}

The results of the consumer acceptability test for the Appenzeller cheese prepared by adding shrimp powder and ripening for approximately $16 \mathrm{wk}$ are shown in Table 5. The cheese colour scores were high for the control cheese and that combined with the highest concentration of shrimp powder. No significant differences in flavour,

Table 3. Colour measurements of the Appenzeller cheese supplemented with shrimp powder

\begin{tabular}{|c|c|c|c|c|c|c|c|c|c|c|c|c|}
\hline \multirow{3}{*}{$\begin{array}{l}\text { Time } \\
\text { (wk) }\end{array}$} & \multicolumn{4}{|c|}{ Lightness (L) } & \multicolumn{4}{|c|}{ Greenness (a) } & \multicolumn{4}{|c|}{ Yellowness (b) } \\
\hline & \multicolumn{4}{|c|}{ Shrimp Powder (\%) } & \multicolumn{4}{|c|}{ Shrimp Powder (\%) } & \multicolumn{4}{|c|}{ Shrimp Powder (\%) } \\
\hline & 0 & 1 & 2 & 3 & 0 & 1 & 2 & 3 & 0 & 1 & 2 & 3 \\
\hline 0 & $\begin{array}{c}63.74 \pm \\
0.98^{\mathrm{b}}\end{array}$ & $\begin{array}{c}64.83 \pm \\
1.31^{\mathrm{a}}\end{array}$ & $\begin{array}{c}63.88 \pm \\
1.26^{\mathrm{b}}\end{array}$ & $\begin{array}{c}62.91 \pm \\
0.47^{\mathrm{c}}\end{array}$ & $\begin{array}{c}-2.99 \pm \\
0.13^{\mathrm{a}}\end{array}$ & $\begin{array}{c}-1.88 \pm \\
1.26^{\mathrm{b}}\end{array}$ & $\begin{array}{c}-1.90 \pm \\
0.24^{b}\end{array}$ & $\begin{array}{c}-1.78 \pm \\
0.21^{b}\end{array}$ & $\begin{array}{l}7.80 \pm \\
0.31^{b}\end{array}$ & $\begin{array}{l}7.58 \pm \\
0.21^{\mathrm{c}}\end{array}$ & $\begin{array}{l}8.31 \pm \\
0.47^{\mathrm{a}}\end{array}$ & $\begin{array}{l}8.39 \pm \\
0.67^{\mathrm{a}}\end{array}$ \\
\hline 3 & $\begin{array}{c}57.06 \pm \\
0.62^{\mathrm{a}}\end{array}$ & $\begin{array}{c}57.92 \pm \\
1.22^{\mathrm{a}}\end{array}$ & $\begin{array}{c}54.97 \pm \\
2.68^{\mathrm{b}}\end{array}$ & $\begin{array}{c}50.19 \pm \\
2.65^{\mathrm{c}}\end{array}$ & $\begin{array}{c}-3.31 \pm \\
0.08^{\mathrm{a}}\end{array}$ & $\begin{array}{c}-1.95 \pm \\
0.20^{\mathrm{c}}\end{array}$ & $\begin{array}{c}-2.18 \pm \\
0.21^{\mathrm{b}}\end{array}$ & $\begin{array}{c}-0.97 \pm \\
0.21^{\mathrm{d}}\end{array}$ & $\begin{array}{l}8.59 \pm \\
0.58^{\mathrm{b}}\end{array}$ & $\begin{array}{l}8.20 \pm \\
0.56^{\mathrm{b}}\end{array}$ & $\begin{array}{l}8.59 \pm \\
0.89^{\mathrm{b}}\end{array}$ & $\begin{array}{c}10.10 \pm \\
0.94^{\mathrm{a}}\end{array}$ \\
\hline 6 & $\begin{array}{c}46.71 \pm \\
1.38^{\mathrm{d}}\end{array}$ & $\begin{array}{c}51.58 \pm \\
1.27^{\mathrm{b}}\end{array}$ & $\begin{array}{c}53.83 \pm \\
0.61^{\mathrm{a}}\end{array}$ & $\begin{array}{c}50.55 \pm \\
2.17^{\mathrm{c}}\end{array}$ & $\begin{array}{c}-2.66 \pm \\
0.38^{\mathrm{a}}\end{array}$ & $\begin{array}{c}-1.95 \pm \\
0.18^{\mathrm{b}}\end{array}$ & $\begin{array}{c}-1.95 \pm \\
0.11^{\mathrm{b}}\end{array}$ & $\begin{array}{c}-1.48 \pm \\
0.55^{\mathrm{c}}\end{array}$ & $\begin{array}{l}6.27 \pm \\
0.25^{\mathrm{c}}\end{array}$ & $\begin{array}{l}8.21 \pm \\
0.08^{b}\end{array}$ & $\begin{array}{c}8.98 \pm \\
0.51^{\text {a }}\end{array}$ & $\begin{array}{l}9.06 \pm \\
1.10^{\mathrm{a}}\end{array}$ \\
\hline 9 & $\begin{array}{c}50.39 \pm \\
2.51^{\mathrm{b}}\end{array}$ & $\begin{array}{c}55.17 \pm \\
1.35^{\mathrm{a}}\end{array}$ & $\begin{array}{c}49.38 \pm \\
2.07^{\mathrm{b}}\end{array}$ & $\begin{array}{c}47.90 \pm \\
2.40^{\mathrm{c}}\end{array}$ & $\begin{array}{c}-2.88 \pm \\
0.53^{\mathrm{a}}\end{array}$ & $\begin{array}{c}-2.07 \pm \\
0.06^{\mathrm{b}}\end{array}$ & $\begin{array}{c}-2.02 \pm \\
0.20^{\mathrm{b}}\end{array}$ & $\begin{array}{c}-2.12 \pm \\
0.32^{\mathrm{b}}\end{array}$ & $\begin{array}{l}7.90 \pm \\
0.70^{b}\end{array}$ & $\begin{array}{l}8.98 \pm \\
0.74^{\mathrm{a}}\end{array}$ & $\begin{array}{l}8.21 \pm \\
0.77^{b}\end{array}$ & $\begin{array}{l}9.00 \pm \\
0.21^{\mathrm{a}}\end{array}$ \\
\hline 12 & $\begin{array}{c}47.27 \pm \\
0.26^{\mathrm{a}}\end{array}$ & $\begin{array}{c}47.03 \pm \\
1.04^{\mathrm{ab}}\end{array}$ & $\begin{array}{c}47.11 \pm \\
0.56^{\mathrm{ab}}\end{array}$ & $\begin{array}{c}46.70 \pm \\
0.25^{\mathrm{b}}\end{array}$ & $\begin{array}{c}-2.93 \pm \\
0.13^{\mathrm{a}}\end{array}$ & $\begin{array}{c}-2.39 \pm \\
0.27^{\mathrm{b}}\end{array}$ & $\begin{array}{c}-1.92 \pm \\
0.12^{\mathrm{c}}\end{array}$ & $\begin{array}{c}-1.65 \pm \\
0.45^{\mathrm{d}}\end{array}$ & $\begin{array}{l}7.15 \pm \\
0.50^{d}\end{array}$ & $\begin{array}{l}9.62 \pm \\
0.25^{\mathrm{c}}\end{array}$ & $\begin{array}{l}7.73 \pm \\
0.50^{\mathrm{b}}\end{array}$ & $\begin{array}{c}10.69 \pm \\
0.87^{\mathrm{a}}\end{array}$ \\
\hline
\end{tabular}

The data are presented as the mean S.D. $(n=15)$. The mean values with different superscript letters in each row are significantly different $(p<0.05)$.

${ }^{\mathrm{NS}}$ Not significantly different. 
Table 4. Texture characteristics of the Appenzeller cheese supplemented with shrimp powder

\begin{tabular}{|c|c|c|c|c|c|c|c|c|}
\hline \multirow{3}{*}{ Time (wk) } & \multicolumn{4}{|c|}{ Cohesiveness } & \multicolumn{4}{|c|}{ "Gumminess } \\
\hline & \multicolumn{4}{|c|}{ Shrimp powder (\%) } & \multicolumn{4}{|c|}{ Shrimp powder (\%) } \\
\hline & Con. & 1.0 & 2.0 & 3.0 & Con. & 1.0 & 2.0 & 3.0 \\
\hline 0 & $0.68 \pm 0.04^{\mathrm{NS}}$ & $0.70 \pm 0.01$ & $0.68 \pm 0.03$ & $0.68 \pm 0.01$ & $\begin{array}{c}1215.42 \pm \\
310.10^{\mathrm{b}}\end{array}$ & $\begin{array}{c}1099.96 \pm \\
66.77^{\mathrm{b}}\end{array}$ & $\begin{array}{c}1032.80 \pm \\
163.30^{\mathrm{b}}\end{array}$ & $\begin{array}{c}1732.87 \pm \\
188.67^{\mathrm{a}}\end{array}$ \\
\hline 3 & $0.57 \pm 0.02^{\mathrm{NS}}$ & $0.56 \pm 0.01$ & $0.56 \pm 0.01$ & $0.54 \pm 0.06$ & $\begin{array}{c}1255.65 \pm \\
116.56^{\mathrm{a}}\end{array}$ & $\begin{array}{c}1288.04 \pm \\
137.48^{\mathrm{a}}\end{array}$ & $\begin{array}{l}938.55 \pm \\
141.88^{\mathrm{b}}\end{array}$ & $\begin{array}{c}1398.56 \pm \\
102.58^{\mathrm{a}}\end{array}$ \\
\hline 6 & $0.72 \pm 0.00^{\mathrm{b}}$ & $0.74 \pm 0.01^{\mathrm{a}}$ & $0.70 \pm 0.01^{\mathrm{c}}$ & $0.71 \pm 0.01^{\mathrm{bc}}$ & $\begin{array}{c}1384.46 \pm \\
303.20^{\mathrm{a}}\end{array}$ & $\begin{array}{c}1119.52 \pm \\
150.95^{\mathrm{a}}\end{array}$ & $\begin{array}{c}544.56 \pm \\
30.38^{\mathrm{b}}\end{array}$ & $\begin{array}{c}760.24 \pm \\
76.13^{\mathrm{b}}\end{array}$ \\
\hline 9 & $0.67 \pm 0.02^{\mathrm{NS}}$ & $0.66 \pm 0.01$ & $0.70 \pm 0.04$ & $0.69 \pm 0.03$ & $\begin{array}{l}1616.06 \pm \\
248.76^{\text {ab }}\end{array}$ & $\begin{array}{c}1634.95 \pm \\
94.89^{\mathrm{ab}}\end{array}$ & $\begin{array}{c}1062.83 \pm \\
551.17^{\mathrm{b}}\end{array}$ & $\begin{array}{c}1823.71 \pm \\
453.88^{\mathrm{a}}\end{array}$ \\
\hline 12 & $0.86 \pm 0.01^{\mathrm{ab}}$ & $0.87 \pm 0.01^{\mathrm{a}}$ & $0.84 \pm 0.01^{\mathrm{c}}$ & $0.84 \pm 0.01^{\mathrm{bc}}$ & $\begin{array}{c}1535.41 \pm \\
38.54^{\mathrm{ab}}\end{array}$ & $\begin{array}{c}1853.97 \pm \\
544.62^{\mathrm{a}} \\
\end{array}$ & $\begin{array}{l}673.04 \pm \\
324.50^{\mathrm{c}}\end{array}$ & $\begin{array}{c}1285.99 \pm \\
176.70^{\mathrm{b}} \\
\end{array}$ \\
\hline \multirow{3}{*}{ Time (wk) } & \multicolumn{4}{|c|}{ Hardness } & \multicolumn{4}{|c|}{ Fracturability } \\
\hline & \multicolumn{4}{|c|}{ Shrimp powder (\%) } & \multicolumn{4}{|c|}{ Shrimp powder (\%) } \\
\hline & Con. & 1.0 & 2.0 & 3.0 & Con. & 1.0 & 2.0 & 3.0 \\
\hline 0 & $\begin{array}{c}1762.18 \pm \\
385.82^{\mathrm{b}}\end{array}$ & $\begin{array}{c}1572.96 \pm \\
82.88^{\mathrm{b}}\end{array}$ & $\begin{array}{c}1515.23 \pm \\
210.49^{\mathrm{b}}\end{array}$ & $\begin{array}{c}2530.55 \pm \\
227.06^{\mathrm{a}}\end{array}$ & $\begin{array}{l}21.36 \pm \\
1.14^{\mathrm{NS}}\end{array}$ & $\begin{array}{c}21.48 \pm \\
0.23\end{array}$ & $\begin{array}{c}21.89 \pm \\
0.87\end{array}$ & $\begin{array}{c}22.29 \pm \\
0.28\end{array}$ \\
\hline 3 & $\begin{array}{c}2219.42 \pm \\
140.72^{\mathrm{a}}\end{array}$ & $\begin{array}{c}2290.69 \pm \\
230.17^{\mathrm{a}}\end{array}$ & $\begin{array}{c}1693.33 \pm \\
281.89^{\mathrm{b}}\end{array}$ & $\begin{array}{c}2639.27 \pm \\
407.44^{\mathrm{a}}\end{array}$ & $\begin{array}{l}21.67 \pm \\
1.51^{\mathrm{NS}}\end{array}$ & $\begin{array}{c}21.47 \pm \\
0.56\end{array}$ & $\begin{array}{c}22.43 \pm \\
1.46\end{array}$ & $\begin{array}{c}29.21 \pm \\
14.23\end{array}$ \\
\hline 6 & $\begin{array}{c}1922.76 \pm \\
416.95^{\mathrm{a}}\end{array}$ & $\begin{array}{c}1512.98 \pm \\
196.21^{\mathrm{c}}\end{array}$ & $\begin{array}{c}1782.31 \pm \\
43.87^{\mathrm{b}}\end{array}$ & $\begin{array}{c}1075.51 \pm \\
101.54^{\mathrm{d}}\end{array}$ & $\begin{array}{l}23.22 \pm \\
2.17^{\mathrm{NS}}\end{array}$ & $\begin{array}{c}22.24 \pm \\
0.66\end{array}$ & $\begin{array}{c}22.89 \pm \\
0.67\end{array}$ & $\begin{array}{c}22.51 \pm \\
1.38\end{array}$ \\
\hline 9 & $\begin{array}{c}2394.94 \pm \\
288.15^{\mathrm{a}}\end{array}$ & $\begin{array}{c}2494.39 \pm \\
190.47^{\mathrm{a}}\end{array}$ & $\begin{array}{c}1541.94 \pm \\
810.79^{\mathrm{b}}\end{array}$ & $\begin{array}{c}2620.15 \pm \\
565.36^{\mathrm{a}}\end{array}$ & $\begin{array}{c}26.87 \pm \\
3.15^{\mathrm{a}}\end{array}$ & $\begin{array}{c}23.56 \pm \\
0.81^{\mathrm{ab}}\end{array}$ & $\begin{array}{c}21.37 \pm \\
0.91^{\mathrm{b}}\end{array}$ & $\begin{array}{l}25.26 \pm \\
3.60^{\mathrm{ab}}\end{array}$ \\
\hline 12 & $\begin{array}{c}1788.07 \pm \\
46.95^{\mathrm{a}}\end{array}$ & $\begin{array}{c}2126.81 \pm \\
616.30^{\mathrm{a}}\end{array}$ & $\begin{array}{c}1805.37 \pm \\
389.26^{\mathrm{b}}\end{array}$ & $\begin{array}{c}1522.34 \pm \\
198.65^{\mathrm{a}}\end{array}$ & $\begin{array}{l}43.69 \pm \\
10.41^{\mathrm{NS}}\end{array}$ & $\begin{array}{c}40.23 \pm \\
17.97\end{array}$ & $\begin{array}{c}27.74 \pm \\
7.74\end{array}$ & $\begin{array}{c}41.11 \pm \\
3.12\end{array}$ \\
\hline \multirow[t]{2}{*}{ Time (wk) } & \multicolumn{2}{|c|}{ Shrimp powder $(\%)$} & & & \multicolumn{3}{|c|}{ Shrimp powder $(\%)$} & \\
\hline & Con. & 1.0 & 2.0 & 3.0 & Con. & 1.0 & 2.0 & 3.0 \\
\hline 0 & $\begin{array}{l}63.59 \pm \\
23.49^{a}\end{array}$ & $\begin{array}{l}20.15 \pm \\
14.40^{b}\end{array}$ & $\begin{array}{l}28.65 \pm \\
21.64^{b}\end{array}$ & $\begin{array}{l}33.21 \pm \\
11.36^{\mathrm{b}}\end{array}$ & $\begin{array}{l}0.84 \pm \\
0.02^{\mathrm{ab}}\end{array}$ & $\begin{array}{l}0.82 \pm \\
0.04^{b}\end{array}$ & $\begin{array}{l}0.85 \pm \\
0.02^{\mathrm{ab}}\end{array}$ & $\begin{array}{l}0.88 \pm \\
0.04^{\mathrm{a}}\end{array}$ \\
\hline 3 & $\begin{array}{l}81.35 \pm \\
32.35^{\mathrm{b}}\end{array}$ & $\begin{array}{l}24.04 \pm \\
22.51^{\mathrm{ab}}\end{array}$ & $\begin{array}{c}73.94 \pm \\
7.29^{\mathrm{a}}\end{array}$ & $\begin{array}{l}64.79 \pm \\
30.42^{b}\end{array}$ & $\begin{array}{l}0.74 \pm \\
0.05^{\mathrm{ab}}\end{array}$ & $\begin{array}{l}0.71 \pm \\
0.01^{b}\end{array}$ & $\begin{array}{l}0.75 \pm \\
0.01^{\mathrm{ab}}\end{array}$ & $\begin{array}{l}0.76 \pm \\
0.02^{\mathrm{a}}\end{array}$ \\
\hline 6 & $\begin{array}{c}53.18 \pm \\
6.77^{\mathrm{a}}\end{array}$ & $\begin{array}{l}18.77 \pm \\
12.47^{\mathrm{bc}}\end{array}$ & $\begin{array}{l}37.03 \pm \\
16.90^{\mathrm{ab}}\end{array}$ & $\begin{array}{c}12.31 \pm \\
9.59^{c}\end{array}$ & $\begin{array}{c}0.89 \pm \\
0.01^{\mathrm{NS}}\end{array}$ & $\begin{array}{c}0.91 \pm \\
0.03\end{array}$ & $\begin{array}{c}0.88 \pm \\
0.04\end{array}$ & $\begin{array}{c}0.86 \pm \\
0.04\end{array}$ \\
\hline 9 & $\begin{array}{l}37.76 \pm \\
15.79^{\mathrm{ab}}\end{array}$ & $\begin{array}{l}49.44 \pm \\
33.00^{\mathrm{a}}\end{array}$ & $\begin{array}{l}17.53 \pm \\
25.69^{\mathrm{ab}}\end{array}$ & $\begin{array}{l}3.24 \pm \\
5.37^{\mathrm{b}}\end{array}$ & $\begin{array}{c}0.83 \pm \\
0.01^{\mathrm{NS}}\end{array}$ & $\begin{array}{c}0.81 \pm \\
0.01\end{array}$ & $\begin{array}{c}0.84 \pm \\
0.05\end{array}$ & $\begin{array}{c}0.83 \pm \\
0.05\end{array}$ \\
\hline 12 & $\begin{array}{l}0.09 \pm \\
0.12^{\mathrm{NS}}\end{array}$ & $\begin{array}{c}0.04 \pm \\
0.18\end{array}$ & $\begin{array}{c}0.09 \pm \\
0.35\end{array}$ & $\begin{array}{c}0.55 \pm \\
0.72\end{array}$ & $\begin{array}{c}1.60 \pm \\
0.72^{\mathrm{NS}}\end{array}$ & $\begin{array}{c}1.88 \pm \\
0.60\end{array}$ & $\begin{array}{c}1.80 \pm \\
0.84\end{array}$ & $\begin{array}{c}1.42 \pm \\
0.69\end{array}$ \\
\hline
\end{tabular}

The data are expressed as the mean S.D. $(n=15)$. The mean values with different superscript letters in each row are significantly different $(p<0.05)$.

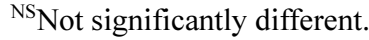

Table 5. Consumer acceptability of the Appenzeller cheese* supplemented with shrimp powder

\begin{tabular}{ccccc}
\hline \hline \multirow{2}{*}{ Characteristics } & \multicolumn{4}{c}{ Shrimp Powder (\%) } \\
\cline { 2 - 5 } & Con. & 1.0 & 2.0 & 3.0 \\
\hline Colour & $7.7 \pm 0.30^{\mathrm{a}}$ & $6.9 \pm 0.43^{\mathrm{ab}}$ & $5.8 \pm 0.51^{\mathrm{b}}$ & $7.4 \pm 0.40^{\mathrm{a}}$ \\
Flavour & $7.0 \pm 0.59^{\mathrm{NS}}$ & $7.0 \pm 0.60$ & $7.6 \pm 0.37$ & $7.3 \pm 0.30$ \\
Texture & $6.6 \pm 0.48^{\mathrm{NS}}$ & $6.3 \pm 0.54$ & $6.6 \pm 0.48$ & $6.4 \pm 0.43$ \\
Overall acceptability & $7.6 \pm 0.34^{\mathrm{NS}}$ & $7.5 \pm 0.37$ & $7.4 \pm 0.31$ & $7.4 \pm 0.43$ \\
Buttery flavour & $7.2 \pm 0.33^{\mathrm{NS}}$ & $6.9 \pm 0.43$ & $6.8 \pm 0.44$ & $7.1 \pm 0.46$ \\
Saltiness & $6.4 \pm 0.40^{\mathrm{NS}}$ & $6.4 \pm 0.43$ & $6.3 \pm 0.47$ & $6.6 \pm 0.40$ \\
Shrimp taste & $5.5 \pm 0.48^{\mathrm{c}}$ & $6.3 \pm 0.45^{\mathrm{bc}}$ & $7.3 \pm 0.30^{\mathrm{ab}}$ & $7.7 \pm 0.30^{\mathrm{a}}$ \\
\hline
\end{tabular}

The data are presented as the mean S.D. $(n=100)$. The mean values with different superscript letters in each row are significantly different $(p<0.05)$.

${ }^{\mathrm{NS}}$ Not significantly different.

*The cheese samples used for the test had been ripened for $16 \mathrm{wk}$. 
texture, overall acceptability, buttery flavour, or saltiness were found between the control and supplemented samples. Thage et al. (2004) and Yvon et al. (2001) have both reported that amino acids such as leucine, isoleucine, and valine are associated with specific cheese flavours. These groups have attained similar consumer acceptability test results depending on the accumulation of flavour-related amino acids in the cheese during ripening as a result of degradation by the action of LAB, along with the use of shrimp powders with similar protein and fat contents in Appenzeller cheese.

\section{Summary}

In the current study, we produced Appenzeller cheese, a cheese with a relatively mild flavour, supplemented with shrimp powder to investigate the effects of adding shrimp powder on the overall quality and characteristics of the cheese. Analysis of the Appenzeller cheese colour revealed the highest value for the control group, and the addition of increasing concentrations of shrimp powder resulted in higher $b$ values. Hardness was the greatest throughout the ripening period for the control cheese and the sample supplemented with $3.0 \%$ shrimp powder. Cohesiveness, fracturability, and springiness were not significantly different among the cheese samples supplemented with shrimp powder. According to the results of the consumer acceptability test, the colours of the control cheese and the sample containing the highest concentration of shrimp powder earned high scores, while no significant differences in flavour, texture, overall acceptability, buttery flavour, or saltiness were observed between the control and supplemented cheeses. Based on these findings, the addition of shrimp powder enhanced product quality without significantly negatively affecting the characteristics of the Appenzeller cheese.

\section{References}

1. AOAC (1990) Official Methods of Analysis. (CIPPO) $15^{\text {th }}$ ed, Association of official Analytical chemists, Washington, D.C. p. 931.

2. Ardõ, Y. (1999) Evaluating Proteolysis by Analysing the N Content of Cheese Fractions. IDF Bull. Int. Dairy Fed. 337, 4-9.

3. Bergamini, C. V., Hynes, E. R., and Zalazar, C. A. (2006) Influence of probiotic bacteria on the proteolysis profile of a semi-hard cheese. Int. Dairy J. 16, 856-866.

4. Bütikofer, M., Rüegg, M., and Ardõ, Y. (1993) Determination of nitrogen fractions in cheese: Evaluation of a collaborative study. Lebensm. Wiss. Technol. 26, 271-275.

5. Cho, E. H., Kim, K. M., and Lee, Y. B. (2011) Quality evaluation of teriyaki sauce processed with shrimp remnants and its physicochemical properties. Korean J. Culinary Res. 17, 184-196.

6. Choi, H. Y., Kim, K H., Chun, S. S., and Bae, I. (2011) Quality properties of appenzeller cheese added with fish surimi. Korean J. Food Sci. Ani. Resour. 31, 232-240.

7. Dahlberg, A. C. and Kosikowski, F. V. (1947) The flavor, voletile acidity and soluble protein of Cheddar and other. J. Dairy Sci. 30, 165-174.

8. Heo, J. H., Shin, H. J., Oh, D. H., Cho, S. K., Yang, C. J., Kong, I. K., Lee, S. S., Choi, K. S., Choi, S. H., Kim, S. C., Choi, H. Y., and Bae, I. (2006) Quality properties of appenzeller cheese added with chlorella. Korean J. Food Sci. Ani. Resour. 26, 525-531.

9. Hull, M. E. (1947) Studies on milk protein colorimetric determination of the partial hydrolysis of the proteins in milk. $J$. Dairy Sci. 30, 881-884.

10. Jeon, J. K. (2006) Effect of chlorella addition on the quality of processed cheese. J. Korean Soc. Food Sci. Nutr. 35, 373377.

11. Juliet, H. (1999) A complete illustrated guide to the cheeses of the world. Lorenz Books. NY, p. 102.

12. Kessler, A., Knusel, H., Raemy, O., Rentsch, F., and Sollberger, H. (1990) Der Tilsiter under Appenzeller. Käasefabrikation, LMZ-Zollikofen. pp. 71-78.

13. Kim, I. S. (2004) Food and Healthy. Shin Kwang publishing Co. Suwon, pp. 160-161.

14. Kim, K. H., Park, B. H., Cho, Y. J., Kim, S. R., and Cho, H. S. (2009) Quality characteristics of shrimp flour added dumpling shell. Korean J. Food Culture 24, 206-211.

15. Kosikowski, F. V. and Mistry, V. V. (1997) Cheese and fermented milk foods, $3^{\text {rd }}$ ed. Edwards Brothers Inc. Michigan. pp. 281-286.

16. Kuchroo, C. N. and Fox, P. F. (1982) Soluble nitrogen in Cheddar cheese. Comparison of extraction procedures. Milchwissenschaft 37, 331-335.

17. Lawrence, R. C., Creamer, L. K., and Filles, J. (1987) Texture development during cheese ripening. J. Dairy Sci. 70, 1748-1760.

18. Lee, G. I. (2004) The quality characteristics of sauce made with shrimp or crab. Korean J. Soc. Food Cookery Sci. 20, 164-169.

19. Lee, K. I., Cho, J. E., and Ahn, H. K. (2007) Volatile flavor compounds identified from the sauces made with waste of shrimp, crab and lobster. The Korean J. Culinary Res. 13, 119-128.

20. Lee, S. H. (2006) How to eat well live well. Cheese, Kimyoungsa, Seoul, Korea, pp. 48.

21. Martin, R. E. and Flick, G. J. (1990) The seafood industry. Osprey Book, NY, pp. 96-99.

22. McSweeney, P. L. H. and Fox, P. F. (1997) Indices of Cheddar cheese ripening. Processed, 5th Cheese Sym., National Dairy Products Research Centre, Moorepark, Fermoy, Co., Cork, Ireland, pp. 73-89. 
23. Oberg, C. J., Davis, L. H., Richardson, G. H., and Ernstrom, C. A. (1986) Manufacture of Cheddar cheese using proteinasenegative mutants of Streptococcus cremoris. J. Dairy Sci. 69, 2974-2981.

24. Park, J. K., Kim, D. G., Choi, C. Y., Jeong, Y. I., Kim, M.Y., Jang, M. K., and Nah, J. W. (2008) Preparation and characterization of lithocholic acid conjugated chitosan oligosaccharide nanoparticles for hydrophobic anticancer agent carriers. Polymer (Korea) 32, 263-269.

25. Puchades, R., Lemieux, L., and Simard, R. E. (1989) Evolution of free amino acids during the ripening of Cheddar cheese containing added lactobacilli strains. J. Food Sci. 54, 885888.

26. Ryu, B. H. (1992) Antitumor immunologic activity of chitosan extracted from shell of shrimp. J. Korean Food Sci. Nutr. 21, 154-162.

27. SAS (1996) SAS/STAT Software for PC. Release 6.11, SAS Institute Inc., Cary, NC, USA.

28. Seo, J. S. and Cho, H. S. (2012) Quality characteristics of fish paste with shrimp powder. Korean J. Food Preservation 19, 519-524.
29. Tejada, L., Abellan, A., Cayuela, J. M., Martinez-Cacha, A., and Fernandez-Salguero, J. (2008) Proteolysis in goat's milk cheese made with calf rennet and plant coagulant. Int. Dairy J. 18, 139-146.

30. Thage, B. V., Rattray, F. P., Laustsenm, M. W., Ardo, Y., Barkholt, V., and Houlberg, U. (2004) Purification and characterization of a branched-chain amino acid aminotransferase from Lactobacillus paracasei subsp. paracasei CHCC 2115. J. Appl. Microbiol. 96, 593-602.

31. Visser, F. M. W. (1977a) Contribution of enzymes from rennet, starter bacteria milk to proteolysis and flavor development in Gouda cheese. 3. protein breakdown; analysis of the soluble nitrogen and amino acid nitrogen fractions. Neth. Milk Dairy J. 31, 188-209.

32. Visser, F. M. W. and De Groot-Mastert, A. E. A. (1977b) Contribution of enzymes from rennet, starter bacteria milk to proteolysis and flavor development in Gouda cheese. 4. protein breakdown; a gel electrophoretical study. Neth. Milk Dairy J. 31, 210-239.

33. Yvon, M. and Rijnen, L. (2001) Cheese flavor formation by amino acid catabolism. Int. Dairy J. 11, 185-201. 